\title{
A novel subset of memory B cells is enriched in autoreactivity and correlates with adverse outcomes in SLE
}

\author{
Matilda W Nicholas ${ }^{1}$, Mary Anne Dooley ${ }^{2}$, Susan L. Hogan ${ }^{3}$, Jennifer Anolik ${ }^{4}$, John \\ Looney ${ }^{4}$, Ingnacio Sanz ${ }^{4}$, and Stephen H Clarke ${ }^{1}$ \\ ${ }^{1}$ Department of Microbiology and Immunology, The University of North Carolina at Chapel Hill, \\ Chapel Hill, NC 27599 \\ 2Department of Medicine, Division of Rheumatology and Immunology, The University of North \\ Carolina at Chapel Hill, Chapel Hill, NC 27599 \\ ${ }^{3}$ Kidney Center and Division of Nephrology and Hypertension, The University of North Carolina at \\ Chapel Hill, Chapel Hill, NC 27599 \\ ${ }^{4}$ Division of Allergy, Immunology and Rheumatology, University of Rochester Medical Center, \\ Rochester NY
}

\begin{abstract}
We previously reported that some systemic lupus erythematosus (SLE) patients have a population of circulating memory B cells with >2-fold higher levels of CD19. We show here that the presence of CD19hi B cells correlates with long-term adverse outcomes. These B cells do not appear anergic, as they exhibit high basal levels of phosphorylated Syk and ERK1/2, signal transduce in response to BCR crosslinking, and can become plasma cells (PCs) in vitro. Autoreactive anti-Smith (Sm) B cells are enriched in this population and the degree of enrichment correlates with the log of the serum anti$\mathrm{Sm}$ titer, arguing that they undergo clonal expansion before PC differentiation. PC differentiation may occur at sites of inflammation, as CD19 ${ }^{\text {hi }} \mathrm{B}$ cells have elevated CXCR3 levels and chemotax in response to its ligand CXCL9. Thus, CD19 ${ }^{\text {hi }} \mathrm{B}$ cells are precursors to anti-self PCs, and identify an SLE patient subset likely to experience poor clinical outcomes.
\end{abstract}

\section{Keywords}

B lymphocytes; memory B cells; systemic lupus erythematosus; CD19; autoimmunity; autoantibodies; Sm antigen

\section{INTRODUCTION}

Systemic lupus erythematosus (SLE) is a severe, autoantibody-mediated disease affecting multiple organ systems. The etiology is poorly understood, but has both genetic and environmental components. Because anti-nuclear antibodies (ANA) are pathogenic in this

\footnotetext{
(c) 2007 Elsevier Inc. All rights reserved.

Corresponding author: Stephen H. Clarke, Department of Microbiology and Immunology, CB\#7290, 804 MEJB, University of North Carolina, Chapel Hill, NC 27599. Phone: (919) 966-3131; FAX: (919) 962-8103; E-mail: shl@ med.unc.edu.

Publisher's Disclaimer: This is a PDF file of an unedited manuscript that has been accepted for publication. As a service to our customers we are providing this early version of the manuscript. The manuscript will undergo copyediting, typesetting, and review of the resulting proof before it is published in its final citable form. Please note that during the production process errors may be discovered which could affect the content, and all legal disclaimers that apply to the journal pertain.
} 
disease[1;2], B cells are thought to play a pivotal role in the development and progression of SLE. Apart from their role as producers of antibody, B cells may also mediate SLE development and pathogenesis through their actions as antigen presenting cells (APCs) and producers of cytokines $[2 ; 3 ; 4 ; 5 ; 6 ; 7 ; 8 ; 9]$. Thus, understanding how B cell self-tolerance is broken in SLE is important to the development of new therapeutic approaches.

With the exception of idiotypic markers such as $9 \mathrm{G} 4$ which is expressed predominantly by autoreactive B cells, no clear phenotypic markers exist to identify precursors of autoantibody producing cells, suggesting that autoreactive cells are generally indistinguishable from cells recognizing foreign antigens. Human autoantibodies are predominantly $\operatorname{IgG}$ and somatically mutated, suggesting that they are the product of germinal center responses. Both class-switched $\left(\operatorname{IgD}{ }^{-}\right)$and $\operatorname{IgM}\left(\operatorname{IgD}^{+}\right)$memory B cells have been isolated from human tonsil, spleen, and peripheral blood. These cells are typically $\mathrm{CD} 38^{-}$and $\mathrm{CD} 27^{+}$, although $\mathrm{CD} 27^{-}$subsets have also been described[10;11] and may frequently contribute a major fraction of the memory $\mathrm{B}$ cell compartment in patients with active SLE[12]. CD $19^{\mathrm{lo}} \mathrm{CD} 38^{\text {hi }}$ plasmablasts have also been identified in human blood, and both of these populations are relatively expanded in SLE patients[13;14]. Upon re-encounter with their cognate antigen, memory B cells proliferate, after which some differentiate into plasma cells and others regenerate the long-lived memory population.

B cell activation is dependent on multiple factors, including specificity and affinity for antigen and the function of co-receptor molecules that act to amplify or dampen signals through the BCR. Balance between these negative and positive modulators is important in establishing B cell tolerance. CD19 is a BCR co-receptor that augments BCR signaling and has become of significant interest in autoimmunity. It is a component of a multimeric protein complex that includes CD21, CD81, and Leu-13[15] and can act as a signaling partner for multiple receptors, including CD21, CD40, CD38, CD72, VLA-4, and Fc $\gamma$ RIIB[16;17;18;19;20]. CD19 is

expressed by all $\mathrm{B}$ cells beginning at the pro-B stage, but is lost along with many other B cellspecific proteins upon plasma cell differentiation[18]. Alterations in CD19 expression by B cells affect their function and differentiation. In the absence of CD19, B cells are hyporesponsive to BCR signaling and generate weak responses to T-dependent antigens, with dramatically reduced germinal center formation; conversely, a high density of CD19 confers hypersensitivity to BCR signaling and vigorous immune responses[21;22]. In mice, as little as a 15\% increase in CD19 expression induces a loss of B cell tolerance and autoantibody production[16;23;24]. Thus, CD19 is critical to setting the threshold levels for the induction of B cell tolerance and activation.

Crosslinking of CD19 with the BCR results in rapid phosphorylation of the cytoplasmic tail of CD19 leading to a processive amplification of Lyn phosphorylation[25]. Activated Lyn phosphorylates the immunoreceptor tyrosine-based activation motifs (ITAMs) on CD79a and CD79b, the signaling subunits of the BCR, which provides a binding site for the Src family tyrosine kinase $\operatorname{Syk}[25 ; 26 ; 27 ; 28]$. Perpetuation of this cascade leads to the activation of the mitogen-activated protein kinases (MAPKs) extracellular signal-regulated kinase (ERK), cJUN NH2-terminal kinase (JNK), and p38 MAPK[27], which induce the transcription of genes controlling proliferation, survival, and differentiation. In addition to its role in Lyn phosphorylation, CD19 leads to the activation of Akt, which enhances B cell survival and metabolic fitness. CD19 signals also synergize with BCR signals by a mechanism independent of $\mathrm{Ca}^{++}$and PKC to enhance the activation of the MAPK ERK1/2[29]. Thus, CD19 contributes to $\mathrm{B}$ cell activation by inducing the activation of multiple pathways crucial to $\mathrm{B}$ cell function in response to antigen stimulation.

Altered CD19 expression is evident in human autoimmunity. B cells from patients s with systemic sclerosis have a 20\% increase in CD19 expression[24], while SLE patient B cells 
have decreased CD19 expression compared to healthy control B cells[24;30;31]. In addition, we, and others, have shown a population of B cells which have 2-3 fold increased levels of CD19 compared to other B cells from the same patient or to healthy control B cells (CD19hi cells) in SLE, ANCA-SVV, and CVID patients[30;32;33]. We previously reported that these $\mathrm{CD} 19^{\text {hi }} \mathrm{B}$ cells have an activated memory phenotype, are class switched, and show evidence of antigen selection[30]. We propose that the increased CD19 expression on $\mathrm{CD} 19^{\text {hi }}$ memory B cells decreases their activation threshold leading to enhanced proliferation, survival, and plasma cell differentiation. If the CD19hi memory B cell subset contains autoreactive B cells, then a lower threshold of activation may lead to chronic activation and production of autoantibody producing plasma cells.

Herein we show that the CD19hi population is enriched in autoreactive B cells, and that the degree of enrichment correlates with autoantibody titer. Consistent with increased autoreactivity, their presence correlates with poor clinical outcomes and possibly with poor clinical response to B cell depletion by rituximab. Analysis of these cells suggests that they are at a very early stage in plasma cell differentiation, are not anergic, and are likely to be homing to sites of inflammation rather than the bone marrow. Thus, CD19hi B cells appear to constitute a population unique to autoimmunity that contribute to autoantibody production and that may play a pivotal role in disease pathogenesis.

\section{MATERIALS AND METHODS}

\section{Healthy Control and Patient Clinical Samples and Data}

Peripheral blood samples were collected from 10 healthy controls (mean age: $36.5 \mathrm{yrs}$, range: 27-54, gender: 8 female, 2 male) and 10 patients (mean age: 37 yrs, range: 23-53, gender: 10 female); in some cases, the same healthy control or patient was used in multiple occasions or experiments. Five of the 10 patients from this study were patients continuing from the original study[30], and the other five were newly identified. Patients were included in this study after informed consent in accordance with our institutional internal review board, and fulfilled at least four of the established American College of Rheumatology 1997 revised criteria for SLE. Samples were gathered during routine clinic visits, and sera obtained from the same blood draw as that for B cell analysis.

Table 1 is a prospective analysis of clinical outcomes of patients remaining in our study since the previous publication[30] and details such as their medications can be found in that manuscript. Clinical outcomes were determined by review of patient records.

Peripheral blood samples were collected into Vacutainer CPT tubes with sodium heprin (BD Biosciences) and sera and peripheral blood mononuclear cells (PBMCs) isolated as per manufacter's protocol. PBMCs were washed once with sterile phosphate buffered saline (PBS) before continuing with any protocol.

\section{Flow Cytometry, Signaling Studies, and FACS}

For surface staining, cells were prepared and stained as previously reported[30]. Signaling and phosphoprotein studies were carried out using the BD Phosflow system as per manufacturer's Protocol 1 (BD Biosciences, San Diego, CA). Briefly, cells were resuspended at $2.5 \times 10^{6}$ cells/ $\mathrm{mL}$ in RPMI $+2 \% \mathrm{FBS}$ and equilibrated at $37^{\circ} \mathrm{C}$ for at least $20 \mathrm{~min}$. An equal volume of prewarmed, 2x solution of goat F(ab') $2 \alpha$-human IgG (10ug/mL final, Southern Biotech, Birmingham, AL) or pansorbin ( $0.1 \%$ final, Calbiochem, La Jolla, CA) was then added with vortexing, and cells were returned to $37^{\circ} \mathrm{C}$ for $10 \mathrm{~min}$. Cells were then immediately fixed by addition of pre-warmed Phosflow Fix Buffer 1, and Protocol 1 followed for permeabilization and staining. Antibodies used were specific for, and labeled with: pSyk-PE, pERK-PE, Syk- 
FITC, pan ERK, pJNK, p-p38-FITC, Ki-67-FITC, CD19-APC, CD20-PE and-APC-Cy7, and CD72-FITC (BD Biosciences, San Diego, CA); pAkt (Thr308) and pAkt (Ser473)-Alexa488 (Cell Signaling Technology, Boston, MA); CD180-PE (RP105), BR3-FITC, TLR4-PE, and TLR9-PE (eBioscience, San Diego, CA). Unlabeled antibodies were labeled using Zenon technology (Invitrogen, San Diego, CA). Appropriate pre-labeled or Zenon labeled isotype controls were used in each experiment.

For propidium iodide (PI) staining, $5 \times 10^{5}$ cells were aliquoted, washed with cold PBS, resuspended in $0.5 \mathrm{~mL}$ cold PBS and permeabilized with $4.5 \mathrm{~mL}$ cold $70 \%$ ethanol for $2 \mathrm{hrs}$ at $-20^{\circ} \mathrm{C}$. Cells were then pelleted, washed with cold PBS, and resuspended in $750 \mathrm{uL}$ of a solution with $0.2 \mathrm{mg} / \mathrm{mL}$ RNase A, $0.02 \mathrm{mg} / \mathrm{mL}$ PI, $0.1 \%$ Triton X-100 (all from Sigma-Aldrich, St. Louis, MO) and anti-CD20-FITC (recognizing the cytoplasmic domain, from BD Pharmingen, San Diego, CA) in PBS and incubated for $1 \mathrm{hr}$ on ice. Cells were then washed with PBS and analyzed by flow cytometry.

For FACS, cells were prepared as described above and stained on ice for $20 \mathrm{~min}$, then washed twice. Antibodies used were specific for, and labeled with: CD19-APC, CD20-APC-Cy7, IgDFITC, and CD38-PE-Cy7 (BD Pharmingen, San Diego, CA). Cells were sorted using settings to obtain maximum purity on one of two high-speed sorters (MoFlo, Dako Cytomation or FACSAria, BD Biosciences). Post-sort analysis determined purity of populations at $>90 \%$.

\section{RNA Extraction and Real Time PCR}

Sorted cell populations were spun down, supernatant removed, and frozen at $-80^{\circ} \mathrm{C}$ until RNA extraction using RNeasy mini columns (Qiagen, San Deigo, CA) as per manufacturer's protocol. The reaction for generation of cDNA was carried out using a poly-A primer and SuperScriptII Reverse Transcriptase (Invitrogen, San Diego, CA) according to manufacturer's protocol.

Real time PCR was carried out using TaqMan Gene Expression Assays, with $\beta$-Actin as an endogenous control, as per manufacturer's protocol (Applied Biosystems, Foster City, CA) on an ABI Prism 7000 Sequence Detection System machine. Data were analyzed using ABI Prism 7000 software relative quantification study parameters. In each case, transcript expression, normalized to $\beta$-actin expression, in sorted CD19hi cells is quantified relative to expression in sorted $\mathrm{CD} 19^{\mathrm{lo}}$ cells from the same patient or in sorted $\mathrm{CD} 19^{+} \mathrm{CD} 38^{-} \mathrm{IgD}^{-}$memory cells relative to expression in all other $\mathrm{CD} 19^{+}$cells sorted from the same healthy control.

\section{ELISpot}

Anti-Sm and anti-IgG ELISpot protocols were adapted from those used in this lab for mouse B cells[34]. Briefly, 96-well filter plates were coated with diluted Sm protein (Immunovision, Springdale, AZ) or anti-human IgG (Bethyl Laboratories, Montgomery, TX). Sorted cells were resuspended in DMEM supplemented with $10 \%$ FBS, 100U/mL Penicillin/Streptomycin (Gibco Invitrogen, San Diego, CA), 0.1\% $\beta$-mercaptoethanol (Gibco Invitrogen, San Diego, $\mathrm{CA}$ ), and $40 \mathrm{ug} / \mathrm{mL}$ transferrin (BD Biosciences, San Diego, CA) and plated at $2.5 \times 10^{4}$ to $5 \times 10^{5}$ cells in $200 \mathrm{uL} /$ well with either media alone or with $15 \mathrm{ug} / \mathrm{mL}$ anti-CD $40,100 \mathrm{U} / \mathrm{mL}$ rhIL-2, 100U/mL rhIL-10, (BD Pharmingen, San Diego, CA), and 0.01\% pansorbin (Calbiochem, La Jolla, CA). In each plate, CD19 hi and CD19 lo B cells, stimulated and nonstimulated, were plated on both Sm and IgG coated wells and incubated for 6 days at $37^{\circ} \mathrm{C}$ with $5 \% \mathrm{CO}_{2}$. They were then washed as previously described and incubated with an antihuman IgG-HRP antibody (Bethyl Laboratories, Montgomery, TX) overnight at $4^{\circ} \mathrm{C}$. The plates were then developed and read as previously described[34]. Counts were normalized to spots per million cells based on the number of cells plated in that well. 
ELISA

The anti-Sm Elisa was carried out as previously described[30] using serum samples obtained from the same draw as the cells sorted and plated in ELISpot. All four patient samples were run on the same plate.

\section{Statistical Methods}

Comparisons for differences in outcomes by CD19 status were done using Fisher exact tests. Fold-changes in all groups were first tested for significant differences from 1.0, representing no difference, using two-sided rank tests. Comparisons between fold-changes between 2 groups were evaluated using 2-sided Wilcoxon rank-sum tests. Comparisons between fold-changes between 3 groups were first evaluated using Kruskal-Wallis tests, then if significant $(\mathrm{p}<0.05)$, a ranked ANOVA was done to determine which groups were different at $p$-value of $\leq 0.05$. Significance between anti-Sm ASCs in the CD $19^{\text {hi }}$ vs. the CD19 ${ }^{\text {lo }} \mathrm{B}$ cell groups was determined by student's $t$ test.

\section{RESULTS}

\section{The presence of CD19hi B cells correlates with adverse clinical outcomes}

We previously reported that the presence of $\mathrm{CD} 19^{\text {hi }} \mathrm{B}$ cells did not correlate with disease activity in a cross-sectional study. However, there was a significant correlation with immunological dysfunction and with severe neurological manifestations (seizures or psychoses), which were seen in 2 of 14 CD19hi SLE patients and none of the 27 CD19 $9^{\text {lo }}$ SLE patients[30]. We now report long-term clinical outcome data from this patient cohort over a five-year period. As seen in Table 1, the presence of a CD19hi population was again significantly associated with severe neurological involvement, as two additional CD19hi SLE patients developed this complication, whereas none of the CD19 ${ }^{\text {lo }}$ SLE patients exhibited neurological symptoms $(\mathrm{p}=0.01)$. In addition, there was a significant correlation with end stage renal disease (ESRD, $\mathrm{p}=0.04$ ), and overall presence of any one of four adverse outcomes (severe neurological complications, ESRD, thrombic thrombocytopenic purpura (TTP), or death due to disease complications, $\mathrm{p}=0.003$ ). Although there was not sufficient statistical power to determine significance in this study, there was also a $>3$-fold increase in diseaserelated deaths in the CD19 ${ }^{\text {hi }}$ SLE patients. Taken together, these findings suggest that presence of the CD19hi memory population identifies a subset of SLE patients with severe disease, and suggests that these cells may play a role in the pathogenesis of neurological and renal manifestations.

\section{CD19hi patients in general have a poor clinical response to rituximab}

Given the increased frequency of severe SLE among CD19hi patients, we evaluated the clinical response to B cell depletion therapy with rituximab, a humanized anti-CD20 monoclonal antibody. In SLE, the response to rituximab is variable; some patients experience long-term clinical remission, while others experience short-term remission or no clinical response[13; 35;36]. In a survey of 17 SLE patients treated with rituximab, five possessed a CD19hi population either before or after treatment with rituximab based on having a frequency of $\mathrm{CD} 19^{\text {hi }} \mathrm{B}$ cells that exceeded two-times the standard deviation above the mean percentage in healthy controls[30]. Clinical response to rituximab was defined as an improvement in the SLAM or SLEDAI score of at least 3 points. Clinical response duration was defined as the time point where these disease activity indexes began to increase (relapse occurred), with the SLAM and/or SLEDAI increasing by at least 3 points and/or an increase in the steroid dose was required for disease control. As shown in Fig. 1, three of four CD19hi patients were shortterm responders to rituximab ( 9 months or less), and 1 did not respond. In contrast, almost half (5 of 12) of CD19 $9^{\text {lo }}$ patients experienced a 12-month or longer remission, and of these, three 
had an extended, ongoing clinical response to rituximab treatment. Of the remaining seven, three were short term and four were non-responders to treatment. Thus, although the sample size is too small for statistical significance, these data suggest that an expanded CD19hi population predicts a poor clinical response to rituximab treatment am ong SLE patients. The possible poor clinical response to anti-CD20 depletion is not for lack of CD20 expression by $\mathrm{CD} 19^{\text {hi }} \mathrm{B}$ cells, as CD19hi $\mathrm{B}$ cells consistently expressed higher levels of CD20 than patient CD19 lo B cells or healthy control B cells (Fig. 1B).

\section{The CD19hi population is enriched in autoreactive $B$ cells}

To determine whether $\mathrm{CD} 19^{\text {hi }} \mathrm{B}$ cells contribute to autoantibody production, we tested whether the CD19hi population is enriched in autoreactive B cells. Since the presence of a CD19hi population is strongly associated with a high anti-Smith $(\mathrm{Sm})$ serum titer[30], we measured the frequency of anti-Sm IgG B cells in the CD19 ${ }^{\text {hi }}$ and non-CD19hi $\left(C D 19^{\text {lo }}\right)$ populations by ELISpot. We sorted CD19hi and CD19 ${ }^{\text {lo }} \mathrm{B}$ cells from four SLE patients, three of whom possessed a positive anti-Sm titer, and induced differentiation to PCs with pansorbin, antiCD40, IL-2, and IL-10 for 6 days on ELISpot membranes coated with purified Sm protein. No anti-Sm antibody secreting cells were observed among the CD19hi or CD19lo B cells from the patient that lacked an anti-Sm titer. However, significantly more anti-Sm IgG secreting cells were present among CD19hi $\mathrm{B}$ cells than among $\mathrm{CD} 19^{\text {lo }} \mathrm{B}$ cells $(\mathrm{p}=0.01$, Fig. $2 \mathrm{~A}$ ) from the remaining three patients. Importantly, the frequency of anti-Sm PCs within the CD19hi population correlated exponentially with the serum anti-Sm $\operatorname{titer}\left(R^{2}=0.99\right.$, Fig. $\left.2 B\right)$, suggesting clonal expansion before differentiation to a PC.

\section{CD19hi cells have a unique basal phosphorylation state}

To determine whether increased CD19 alters BCR signaling, we measured basal and BCR stimulated levels of phosphorylated signaling molecules. We compared the levels of phosphorylated CD19, Syk, Akt, and the MAPKs ERK1/2, JNK, and p38 in CD19hi B cells with those of CD19 $9^{\text {lo }} \mathrm{B}$ cells from the same patient and healthy control B cells. The limited numbers of CD19hi B cells that can be obtained precluded the use of standard Western blotting methods; thus, we used flow cytometry to detect phosphorylated proteins in these cells. Flow cytometry had the added benefit of also measuring the frequency of B cells within a population that exhibited increased phosphorylation of a given protein.

To measure basal phosphorylation levels of these proteins, we stained for their presence immediately following purification of peripheral blood monocytes (PBMCs). In each case a healthy control blood sample was stained at the same time. There was a modest but significant increase in the median fluorescence intensity (MFI) for phosphorylated CD19 (pCD19) in $\mathrm{CD} 19^{\text {hi }} \mathrm{B}$ cells compared to $\mathrm{CD} 19^{\mathrm{lo}} \mathrm{B}$ cells (average $=1.5$ fold, $\mathrm{p}=0.03$ ). However, the increase in the MFI for total CD19 protein (average $=2.9$ fold, $p=0.03$, Fig. $3 \mathrm{~A}$ ) was significantly higher than the increase for $\mathrm{pCD} 19(\mathrm{p}=0.02)$. Thus, a smaller proportion of $\mathrm{CD} 19$ was phosphorylated in CD19hi B cells compared to CD19 $9^{\text {lo }}$ cells. Because CD19 phosphorylation amplifies Syk activation[37], we were surprised to find that despite a lower frequency of CD19 phosphorylation, nearly all CD19hi $\mathrm{B}$ cells displayed significantly elevated levels of phosphorylated Syk (pSyk) in contrast to the $\mathrm{CD} 19^{\mathrm{lo}} \mathrm{B}$ cells from the same patient and to healthy control B cells (Fig. 3B-D). The MFI of pSyk in CD19hi cells was an average of 2.9fold greater than that for CD19 ${ }^{\text {lo }} \mathrm{B}$ cells from the same patient or healthy control B cells. Likewise, nearly all CD19hi $\mathrm{B}$ cells exhibited significantly elevated levels of pERK1/2 (average 2.9-fold) in contrast to $\mathrm{CD} 19^{\text {lo }} \mathrm{B}$ cells from the same patient and to healthy control B cells (Fig. 3B-D). Levels of total Syk and ERK protein were also elevated in CD19hi as compared to $\mathrm{CD} 19^{\text {lo }} \mathrm{B}$ cells (average 1.8- and 1.4-fold, respectively, Fig. 3C and D), but these increases were significantly lower than increases in pSyk and pERK1/2 levels (Fig. 3D). It should be noted that the pan-ERK antibody recognizes ERK family members in addition to ERK1/2, and 
therefore the increased ERK levels detected by this antibody may have overestimated the increase in ERK1/2 expression. In contrast to Syk and ERK, we observed no significant differences in basal phosphorylation levels of Akt or the MAP kinases p38 or JNK between patient $\mathrm{CD} 19^{\mathrm{hi}} \mathrm{B}$ cells and patient $\mathrm{CD} 19^{\mathrm{lo}}$ or healthy control B cells. In the case of Akt, no increase in phosphorylation was detected at either phosphorylation site (Fig. 3D). Thus, ex vivo $\mathrm{CD} 19^{\text {hi }} \mathrm{B}$ cells exhibit an unusual phosphorylation phenotype, consistent with recent antigen stimulation. Despite a lower frequency of phosphorylated CD19, nearly all cells exhibited increased levels of pSyk and pERK1/2, but not increased phosphorylation of other measured molecules downstream of the BCR and CD19.

\section{CD19hi $B$ cells are responsive to BCR stimulation}

Since constitutively elevated pERK levels are associated with B cell tolerance[38], we sought to determine whether crosslinking the $\mathrm{BCR}$ on $\mathrm{CD} 19^{\text {hi }} \mathrm{B}$ cells results in signal transduction and plasma cell differentiation. To determine whether BCR signaling is intact in CD19hi $\mathrm{B}$ cells, healthy control and SLE B cells were stimulated with anti-IgG or pansorbin for 10 minutes and the levels of phosphorylated molecules determined by flow cytometry. Although the kinetics of phosphorylation may vary for each molecule examined, due to limited cell number we sought a time point at which phosphorylation of all measured molecules could be observed in healthy control and SLE B cells. All five signaling intermediates and CD19 were phosphorylated upon BCR stimulation in healthy control B cells and SLE CD19 ${ }^{\text {lo }} \mathrm{B}$ cells (Fig. $4 \mathrm{~A}-\mathrm{C}$ ), although a somewhat higher percentage of $\mathrm{CD} 19^{\text {lo }} \mathrm{B}$ cells than healthy control B cells phosphorylated these molecules (Fig. 4C). This was especially true for Syk $(\mathrm{p}=0.004)$ and ERK1/2 ( $\mathrm{p}=0.01)$, consistent with reports that SLE B cells are hyperresponsive to BCR stimulation[30;39;40;41;42]. Importantly, BCR crosslinking increased the levels of phosphorylated CD19, p38, JNK, and Akt in SLE CD19hi B cells similarly to healthy control and CD19lo B cells (Fig. 4A and B). The frequency of CD19 hi B cells that increased the levels of each of these phosphorylated proteins was also similar to that of CD19 $9^{\text {lo }}$ and healthy control B cells (Fig. 4C). In contrast, SLE CD19hi B cells exhibited little or no increase in the already high basal levels of pSyk and pERK1/2 (Fig. 4A and B), or in the percentage of cells positive for pSyk and pERK1/2 (Fig. 4C). Interestingly, the basal pSyk and pERK1/2 levels in $\mathrm{CD} 19^{\text {hi }} \mathrm{B}$ cells were similar to those reached by healthy controls and SLE CD $19^{\text {lo }} \mathrm{B}$ cells after $\mathrm{BCR}$ crosslinking, suggesting that ex vivo $\mathrm{CD} 19^{\text {hi }} \mathrm{B}$ cells have already maximally phosphorylated these molecules. Altogether, these data indicate that $\mathrm{CD} 19^{\mathrm{hi}} \mathrm{B}$ cells are not refractory to BCR signaling.

To determine whether CD19hi $\mathrm{B}$ cells can be activated to become ASCs, we determined the frequency of $\mathrm{IgG}$ antibody-secreting cells in $\mathrm{CD} 19^{\text {hi }}$ and $\mathrm{CD} 19^{\text {lo }} \mathrm{B}$ cell populations by an ELISpot assay with and without stimulation. As shown in Fig. 4D, an average of only $0.05 \%$ (SEM $0.03 \%$ ) of CD19 ${ }^{\text {hi }}$ cells spontaneously secreted IgG, $\sim 7$-fold less than CD19 ${ }^{\text {lo }}$ B cells $(0.34 \%$, SEM $0.16 \%)$. However, stimulation with pansorbin, anti-CD40, IL-2, and IL-10, a cocktail previously shown to induce robust IgG secretion in memory B cells[43], induced an average of $14.6 \%$ (SEM $4.51 \%$ ) of CD19hi $\mathrm{B}$ cells to secrete $\mathrm{IgG}$, nearly twice that seen with CD19 ${ }^{\text {lo }} \mathrm{B}$ cells $\left(7.9 \%\right.$, SEM 2.6\%). This may be due to differences in the frequency of $\operatorname{IgG}^{+}$ $\mathrm{B}$ cells in each population or to an increased propensity of CD19hi $\mathrm{B}$ cells to become antibodysecreting cells. Thus, the ability of CD19hi $\mathrm{B}$ cells to signal in response to BCR ligation and their ability to differentiate to antibody-secreting cells upon stimulation suggest that CD19hi B cells are not anergic.

\section{CD19hi cells have a pre-plasma cell transcription profile}

Our previous analysis suggested that CD19hi B cells are activated memory B cells. However, the relationship between autoreactive $\mathrm{B}$ cell frequency and serum autoantibody titers suggests a close relationship between these cells and the plasma cell pool in these patients. Thus, we 
sought to determine whether these cells were at an early stage in plasma cell differentiation by measuring the levels of B cell- and plasma cell-specific transcription factors by RQ RT-PCR. RNA from sorted CD $19^{\text {hi }}$ and CD19lo B cells from three patients was used to determine expression levels of the B cell-specific transcription factors Pax-5 and Bcl-6 and the plasma cell-specific transcription factors Blimp-1, IRF-4 and XBP-1. During differentiation to an antibody secreting cell, Pax-5 and Bcl-6 are downregulated, and IRF-4, Blimp-1, and XBP-1 are upregulated[44]. As shown in Fig. 5A, CD19 ${ }^{\text {hi }} \mathrm{B}$ cells showed significant downregulation of Pax -5 and smaller but consistent downregulation of Bcl-6 compared to CD $19^{\text {lo }} \mathrm{B}$ cells (average $\mathrm{RQ}=0.34$ and 0.49 , respectively). However, they showed no significant upregulation of Blimp-1, IRF-4, or XBP-1 expression (Fig 5A). Since $>70 \%$ of CD19hi cells are $\operatorname{IgD}^{-} \mathrm{CD} 38^{-}$[30], we sorted $\mathrm{IgD}^{-} \mathrm{CD} 38^{-}$memory $\mathrm{B}$ cells and all other $\mathrm{CD} 19^{+} \mathrm{B}$ cells from three healthy controls and measured expression of these transcription factors to determine the expression profile in healthy control memory B cells (Fig. 5B). No significant differences were observed between the cells of these populations, including in Pax-5 expression (average $\mathrm{RQ}=1.4$ ). In addition, $\mathrm{XPB}-1$ expression was decreased in healthy control memory $\mathrm{B}$ cells compared to non-memory B cells, whereas it was not in CD19hi memory B cells compared to CD19 ${ }^{\text {lo }} \mathrm{B}$ cells. Thus, the low Pax-5 levels and relatively higher XPB-1 levels seen in $\mathrm{CD} 19^{\text {hi }} \mathrm{B}$ cells are not a general characteristic of memory B cells, suggesting that CD19hi cells are at an early pre-plasma differentiative stage.

Since our findings indicate that $\mathrm{CD} 19^{\text {hi }} \mathrm{B}$ cells may clonally expand before becoming plasma cells, we determined whether they were actively undergoing cell division. As expected of circulating B cells, CD19hi B cells were not actively undergoing cell division. As shown in Fig. 5A and Table 2, CD19hi B cells did not express high levels of Ki-67, a protein present only in proliferating cells, or exhibit an increase in DNA content, as measured by PI staining. Thus, CD19hi B cells are not in $\mathrm{S}$ phase. However, they exhibited a small but consistent (average 1.7 fold) increase in Ki-67 staining (Table 2), consistent with cells in $\mathrm{G}_{1}$ phase or just entering or leaving S phase[45;46;47]. Thus, CD19hi B cells are not actively undergoing cell division, indicating the clonal expansion that they undergo before becoming plasma cells occurs after they exit the circulation.

\section{CD19hi $B$ cells have an unusual chemokine receptor expression profile}

Long-lived plasma cells reside primarily in the bone marrow, and thus to determine whether the $\mathrm{CD} 19^{\text {hi }} \mathrm{B}$ cells are likely to be homing to the bone marrow, we compared the transcript levels of CXCR4 and CXCR5 in CD19hi vs. CD19lo B cells. CXCR5 retains cells in the follicles of secondary lymphoid tissues ([48]), and is normally downregulated during plasma cell differentiation ([49]), while CXCR4 is responsible for directing plasma cell precursors to the bone marrow and is normally upregulated during plasma cell differentiation ([50]). As shown in Fig. 6A, CXCR4 transcripts were significantly lower in CD19hi $\mathrm{B}$ cells of all three patients relative to $\mathrm{CD} 19^{\text {lo }} \mathrm{B}$ cells (average $\mathrm{RQ}=0.1$ ), as were $\mathrm{CXCR} 5$ transcripts in two of the three patients (average $\mathrm{RQ}=0.36$, overall average $\mathrm{RQ}=0.7$ ). Similar to $\mathrm{CD} 19^{\mathrm{hi}} \mathrm{B}$ cells, healthy control memory B cells had lower transcript levels of CXCR4 and CXCR5 compared to nonmemory B cells (average RQ $=0.4$ and 0.7 , respectively, Fig. $6 \mathrm{~B}$ ), but these decreases were less pronounced than in CD19hi $\mathrm{B}$ cells. While CXCR5 transcripts were similarly decreased in $\mathrm{CD} 19^{\text {hi }}$ and healthy control memory B cells relative to their respective controls (Fig. 6A and $\mathrm{B})$, the relative decrease in CXCR4 transcripts by CD19 ${ }^{\text {hi }} \mathrm{B}$ cells was $\sim 4$ times greater than that in healthy control memory B cells (Fig. 6A and B). Thus, CD19hi B cells differ from healthy control memory $\mathrm{B}$ cells in having a greater reduction in CXCR4 transcripts, casting doubt on the ability of these cells to home to the bone marrow.

Since CD19hi B cells may not home to the bone marrow, we determined whether CD19hi B cells could be homing to sites of inflammation. CXCR3 levels are elevated on a subset of 
memory B cells and plasma cells[50;51;52], in addition to T cells[53], and directs migration to sites of inflammation where CXCR3 ligands are present at high concentrations[51]. As seen in Fig. 7A, CXCR3 transcript levels were dramatically higher in CD19 ${ }^{\text {hi }} \mathrm{B}$ cells compared to $\mathrm{CD} 19^{\text {lo }} \mathrm{B}$ cells of all three patients tested (average $\mathrm{RQ}=14.2$, range $=7.6-24$ ). This increase was much higher than the $\sim 2$-fold increase in CXCR3 transcripts seen in healthy control memory B cells compared to non-memory B cells (Fig. 6B). The increase in CXCR3 transcript levels is reflected by a significant increase in CXCR3 protein on the cell surface of CD19hi $B$ cells (Fig. 6C). These results suggest that CD19hi $\mathrm{B}$ cells may home to sites of inflammation.

To confirm that increased expression of CXCR3 by CD19hi $\mathrm{B}$ cells is functionally significant, we determined the ability of CD19hi B cells to migrate in response to CXCR3 and CXCR4 ligands. As shown in Fig 6D, CD19 $9^{\text {hi }}$ B cells migrated efficiently in response to the CXCR3 ligand CXCL9, but little or not at all in response to the CXCR4 ligand CXCL12 or to media alone. These data affirm that $\mathrm{CD} 19^{\mathrm{hi}} \mathrm{B}$ cells are unlikely to migrate to the bone marrow and indicate that the increased expression of CXCR3 on these cells is functionally relevant, supporting the idea that $\mathrm{CD} 19^{\text {hi }} \mathrm{B}$ cells are homing to sites of inflammation.

\section{DISCUSSION}

CD19hi B cells constitute a novel population of memory B cells that are present at a high frequency in the peripheral blood of some SLE and ANCA-vasculitis patients[30]. Relevance of the $\mathrm{CD} 19^{\text {hi }} \mathrm{B}$ cell population to autoimmunity is indicated by the 3 - to 10 -fold enrichment in anti-Sm B cells compared to the CD19 ${ }^{\text {lo }}$ population, and by the fact that the degree of enrichment correlates with the level of serum anti-Sm antibody. In contrast, the frequency of anti-Sm CD19 ${ }^{\text {lo }} \mathrm{B}$ cells is not different between patients regardless of anti-Sm titer. Consistent with an involvement in autoantibody production, CD19hi $\mathrm{B}$ cells do not appear to be anergic, as BCR crosslinking induces phosphorylation of CD19, Akt, JNK and p38 to levels comparable to those in $\mathrm{CD} 19^{\text {lo }} \mathrm{B}$ cells from the same patient and to those in healthy control B cells. In addition, BCR crosslinking, in conjunction with CD40 and cytokine signals, induces a high frequency of CD19 ${ }^{\text {hi }} \mathrm{B}$ cells to become PCs. Thus, the CD19hi B cell subset likely includes the precursors to the majority of anti-Sm PCs in these patients. The finding that autoantibodies specific for other small nuclear ribonucleoproteins correlate with the presence of this subset in SLE patients[30] suggests that the CD19hi subset likely includes autoreactive B cells of other specificities.

The frequency of anti-Sm B cells in the CD19 ${ }^{\text {hi }}$ population correlates linearly with the log of the anti-Sm titer, such that a doubling of the frequency is associated with a 100 -fold increase in titer. This suggests that $\mathrm{CD} 19^{\text {hi }} \mathrm{B}$ cells undergo clonal expansion before becoming PCs, and suggests further that the degree of clonal expansion varies as a function of CD19hi $\mathrm{B}$ cell frequency. A possible explanation is that $\mathrm{CD} 19^{\text {hi }} \mathrm{B}$ cells activate other inflammatory cells at the site of plasma cell differentiation that enhance their proliferation, thereby creating a positive feedback loop. Thus, the more CD19hi $\mathrm{B}$ cells present at the sites of differentiation, the greater the proliferation and the greater number of plasma cells generated. The cells and cytokines involved in driving CD19hi $\mathrm{B}$ cell clonal expansion remain to be identified, but $\mathrm{T}$ cell activation would be consistent with the elevated surface expression of MHCII and CD86 in CD19hi $\mathrm{B}$ cells[30], and with the ability of $\mathrm{T}$ cells to secrete cytokines known to induce B cell proliferation.

CD19hi $\mathrm{B}$ cells have high basal levels of pSyk and pERK1/2, equivalent to those in CD19 ${ }^{\text {lo }}$ and healthy control B cells after strong BCR crosslinking (Fig. 4B), suggesting that they have recently received a BCR activating signal. The absence of elevated basal levels of pAkt in CD19hi B cells seemingly contradicts the involvement of a BCR signal, since BCR signals induce Akt phosphorylation[54]. The main pathway for both ERK1/2 and Akt phosphorylation 
is the recruitment of phosphatidylinositol 3-kinase (PI3K) to the BCR complex by CD19 and its activation by Syk[27;55;56]. Thus, the high basal phosphorylation of Syk and ERK1/2 suggests that the Syk/PI3K/ERK pathway is activated in CD19hi B cells. One explanation for the lack of Akt phosphorylation is that it may be more transient than ERK or Syk phosphorylation [54], and therefore lost by the time the the cells can be analyzed. Alternatively, Akt phosphorylation may be regulated downstream or independently of PI3K activation. Indeed, Li and Carter[29] have demonstrated that CD19 signals synergize with BCR signals to induce ERK1/2 activation at a point downstream of PI3K in B cells. Since Syk phosphorylation is also downstream of CD19 phosphorylation, this could explain the high levels of pSyk in these cells as well.

The low Pax-5 expression by CD $19^{\text {hi }} \mathrm{B}$ cells suggests that CD19hi $\mathrm{B}$ cells are at an early stage in plasma cell differentiation. This level of Pax-5 expression is not a characteristic of memory B cells in general, since healthy control memory B cells express levels of Pax-5 that are not different from non-memory B cells (Fig. 5B). Pax-5 is required for B cell differentiation and activates the expression of genes that maintain $\mathrm{B}$ cell identity[44], including CD19. Thus, the low levels of Pax-5 expression by CD19hi B cells suggest that these cells are differentiating away from a B cell identity. In addition, although CD19 ${ }^{\text {hi }}$ and CD19 ${ }^{\text {lo }} \mathrm{B}$ cells have similar transcript levels of XBP-1, a transcriptional activator required for plasma cell differentiation, healthy control memory B cells express considerably less XBP-1 transcript levels than control B cells, suggesting that XBP-1 has increased in CD19hi B cells. Since Pax-5 represses the expression of XBP-1 [57], increased XBP-1 may follow from low Pax-5 levels. We did not observe evidence of increased Blimp-1 transcript levels, and since transcription of PDRM1, the gene for human Blimp-1, is repressed by Bcl-6[58], this is consistent with the normal expression of Bcl- 6 by CD19hi B cells. Blimp-1 is required for full plasma cell differentiation and antibody secretion, but not for early plasmablast or pre-plasma cell formation[59]. Blimp-1 represses cell division[60], and thus low Blimp-1 levels is compatible with our hypothesis that $\mathrm{CD} 19^{\text {hi }} \mathrm{B}$ cells undergo clonal expansion before PC differentiation.

Chemokine receptor expression suggests a possible location for PC differentiation by CD19hi B cells. Down-regulation of CXCR4 and non-responsiveness to its ligand CXCL12 suggests that $\mathrm{CD} 19^{\text {hi }} \mathrm{B}$ cells are not migrating to the bone marrow, a common location for long-lived PC differentiation[61]. Instead, our findings suggest that these cells are likely to be transiting to sites of inflammation for PC differentiation, guided by high levels of CXCR3. CXCR3 transcripts are $\sim 14$-fold higher in CD19 ${ }^{\text {hi }} \mathrm{B}$ cells than in control CD19 ${ }^{\text {lo }} \mathrm{B}$ cells, a finding reflected in an increase in CXCR3 protein expression on the cell surface. This CXCR3 is functional, as CD19 ${ }^{\text {hi }} \mathrm{B}$ cells chemotax in response to the CXCR3 ligand CXCL9. A subset of human memory B cells and plasmablasts express CXCR3, and the expression of this chemokine receptor is maintained after plasma cell differentiation[50;51;52]. The CXCR3 ligands CXCL9, CXCL10 and CXCL11 are highly expressed in peripheral sites of inflammation, where, in autoimmunity and other highly inflammatory states, B cells can differentiate to tissue-resident PCs [51;52;62;63;64]. For example, CXCR3 ligands are elevated in the skin of patients with cutaneous lupus[65], the synovium of RA patients[64], and the kidney and serum of SLE patients[66;67;68]. Interestingly, CXCR3 ligands are elevated in the CNS of SLE patients with neurological involvement [69;70;71] and pre-PCs and PCs have been found in the intrathecal tissue of SLE patients with CNS involvement[71]. Migration to the kidney and CNS could account for the increased incidences of ESRD and severe neurological dysfunction in CD19hi patients. Pathology may arise from locally high concentrations of autoantibodies, and/or from the production of cytokines and activation of other inflammatory cells[2;3;4;5;6;7;8;9].

The presence of CD19hi B cells in a subset of SLE patients may have implications for prognosis and treatment. Although rituximab is a promising new therapy for SLE, not all patients have 
a robust clinical response[72]. This may be because not all $\mathrm{B}$ cell subsets are equally susceptible to depletion. While PB B cells and follicular B cells are depleted efficiently, marginal zone and memory $\mathrm{B}$ cells are less responsive to depletion, and plasma cells, which do not express CD20, are not depleted at all[13;73]. We do not yet know how susceptible the CD19hi B cells are to rituximab depletion, although they express high levels of CD20 compared to CD19 ${ }^{\text {lo }} \mathrm{B}$ cells from the same patient and from healthy control B cells. However, our data raise the possibility that CD19hi patients are poor clinical responders to rituximab. This finding further differentiates CD19 ${ }^{\text {hi }}$ patients as a distinct subgroup of SLE patients and suggests a predictive test for clinical response to rituximab. Some of us have recently shown that SLE patients with high titers of antibodies to Sm, snRNP, Ro, and La have decreased responsiveness to rituximab [35]. This is consistent with the findings reported here, since the presence of CD19 ${ }^{\text {hi }} \mathrm{B}$ cells is associated with elevated titers of antibodies to Sm and other snRNP antigens[30].

In summary, the enrichment of autoreactive B cells within the CD19hi population and the correlation of this enrichment with the serum autoantibody titer link this population to autoimmunity. The presence of CD19hi B cells delineates a subgroup of SLE patients with increased adverse clinical outcomes, and possibly a decreased response to rituximab treatment. These findings not only point to this population as a possible therapeutic target, but also as a marker for separating SLE patients into etiological and pathological subgroups that might benefit from different treatment modalities.

\section{Abbreviations}

$\begin{array}{ll}\text { ANCA } & \text { anti-neutrophil cytoplasmic antibody } \\ \text { SVV } & \text { small vessel vasculitis } \\ \text { CVID } & \text { common variable immunodeficiency } \\ \text { PB } & \text { peripheral blood } \\ \text { Sm } & \text { Smith } \\ \text { SLE } & \text { systemic lupus erythematosis } \\ \text { BCR } & \text { B cell receptor } \\ \text { HC } & \text { healthy control } \\ \text { ANA } & \text { anti-nuclear antibodies } \\ \text { Ig } & \text { immunoglobulin } \\ \text { ASC } & \text { antibody secreting cells } \\ \text { TLR } & \text { toll-like receptor }\end{array}$

\section{Acknowledgments}

We gratefully acknowledge and thank the Flow Cytometry Facility at the University of North Carolina and the Surgical Oncology Research Facility (SORF) at Duke University. We also extend our thanks to Julie Hamera and Dr. Robert Roubey for their help in acquiring patient samples and to Drs. Ron Falk and Donna Bunch for support and suggestions. Finally, we wish to thank the patients and healthy controls whose generous donations made this work possible.

This work was supported by National Institutes of Health grants AI29576 and AI43587. M.W.N. was supported by an NIEHS Fellowship, F30 ES014519.

\section{REFERENCES}

1. Hahn BH. Antibodies to DNA. N Engl J Med 1998;338:1359-1368. [PubMed: 9571257] 
2. Su W, Madaio MP. Recent advances in the pathogenesis of lupus nephritis: autoantibodies and B cells. Semin Nephrol 2003;23:564-568. [PubMed: 14631564]

3. Harris DP, Haynes L, Sayles PC, Duso DK, Eaton SM, Lepak NM, Johnson LL, Swain SL, Lund FE. Reciprocal regulation of polarized cytokine production by effector B and T cells. Nat Immunol 2000;1:475-482. [PubMed: 11101868]

4. Bijl M, Horst G, Limburg PC, Kallenberg CG. Expression of costimulatory molecules on peripheral blood lymphocytes of patients with systemic lupus erythematosus. Ann Rheum Dis 2001;60:523-526. [PubMed: 11302879]

5. Chan OT, Hannum LG, Haberman AM, Madaio MP, Shlomchik MJ. A novel mouse with B cells but lacking serum antibody reveals an antibody-independent role for B cells in murine lupus. J Exp Med 1999;189:1639-1648. [PubMed: 10330443]

6. Shlomchik MJ, Madaio MP, Ni D, Trounstein M, Huszar D. The role of B cells in lpr/lpr-induced autoimmunity. J Exp Med 1994;180:1295-1306. [PubMed: 7931063]

7. Chan OT, Madaio MP, Shlomchik MJ. The central and multiple roles of B cells in lupus pathogenesis. Immunol Rev 1999;169:107-121. [PubMed: 10450512]

8. Roth R, Gee RJ, Mamula MJ. B lymphocytes as autoantigen-presenting cells in the amplification of autoimmunity. Ann N Y Acad Sci 1997;815:88-104. [PubMed: 9186642]

9. Mamula MJ, Fatenejad S, Craft J. B cells process and present lupus autoantigens that initiate autoimmune T cell responses. J Immunol 1994;152:1453-1461. [PubMed: 8301145]

10. Ehrhardt GR, Hsu JT, Gartland L, Leu CM, Zhang S, Davis RS, Cooper MD. Expression of the immunoregulatory molecule FcRH4 defines a distinctive tissue-based population of memory B cells. J Exp Med 2005;202:783-791. [PubMed: 16157685]

11. Fecteau JF, Cote G, Neron S. A new memory CD27-IgG+ B cell population in peripheral blood expressing VH genes with low frequency of somatic mutation. J Immunol 2006;177:3728-3736. [PubMed: 16951333]

12. Wei C, Anolik JH, Cappione A, Huggins J, Zheng B, Milner E, Sanz I. A new population of cell lacking expression of $\mathrm{C} 27$ represents a notable component of the B cell memory compartment in SLE. J Immunol 2007;178

13. Anolik JH, Barnard J, Cappione A, Pugh-Bernard AE, Felgar RE, Looney RJ, Sanz I. Rituximab improves peripheral B cell abnormalities in human systemic lupus erythematosus. Arthritis Rheum 2004;50:3580-3590. [PubMed: 15529346]

14. Odendahl M, Jacobi A, Hansen A, Feist E, Hiepe F, Burmester GR, Lipsky PE, Radbruch A, Dorner T. Disturbed peripheral B lymphocyte homeostasis in systemic lupus erythematosus. J Immunol 2000;165:5970-5979. [PubMed: 11067960]

15. Tedder TF, Zhou LJ, Engel P. The CD19/CD21 signal transduction complex of B lymphocytes. Immunol Today 1994;15:437-442. [PubMed: 7524521]

16. Tedder TF, Inaoki M, Sato S. The CD19-CD21 complex regulates signal transduction thresholds governing humoral immunity and autoimmunity. Immunity 1997;6:107-118. [PubMed: 9047233]

17. Bradbury LE, Kansas GS, Levy S, Evans RL, Tedder TF. The CD19/CD21 signal transducing complex of human B lymphocytes includes the target of antiproliferative antibody-1 and Leu-13 molecules. J Immunol 1992;149:2841-2850. [PubMed: 1383329]

18. Uckun FM, Burkhardt AL, Jarvis L, Jun X, Stealey B, Dibirdik I, Myers DE, Tuel-Ahlgren L, Bolen JB. Signal transduction through the CD19 receptor during discrete developmental stages of human B-cell ontogeny. J Biol Chem 1993;268:21172-21184. [PubMed: 7691807]

19. Xiao J, Messinger Y, Jin J, Myers DE, Bolen JB, Uckun FM. Signal transduction through the beta1 integrin family surface adhesion molecules VLA-4 and VLA-5 of human B-cell precursors activates CD19 receptor-associated protein-tyrosine kinases. J Biol Chem 1996;271:7659-7664. [PubMed: 8631803]

20. Kitanaka A, Ito C, Coustan-Smith E, Campana D. CD38 ligation in human B cell progenitors triggers tyrosine phosphorylation of CD19 and association of CD19 with lyn and phosphatidylinositol 3kinase. J Immunol 1997;159:184-192. [PubMed: 9200454]

21. Engel P, Zhou LJ, Ord DC, Sato S, Koller B, Tedder TF. Abnormal B lymphocyte development, activation, and differentiation in mice that lack or overexpress the CD19 signal transduction molecule. Immunity 1995;3:39-50. [PubMed: 7542548] 
22. Sato S, Steeber DA, Tedder TF. The CD19 signal transduction molecule is a response regulator of B-lymphocyte differentiation. Proc Natl Acad Sci U S A 1995;92:11558-11562. [PubMed: 8524803]

23. Inaoki M, Sato S, Weintraub BC, Goodnow CC, Tedder TF. CD19-regulated signaling thresholds control peripheral tolerance and autoantibody production in B lymphocytes. J Exp Med 1997;186:1923-1931. [PubMed: 9382890]

24. Sato S, Hasegawa M, Fujimoto M, Tedder TF, Takehara K. Quantitative genetic variation in CD19 expression correlates with autoimmunity. J Immunol 2000;165:6635-6643. [PubMed: 11086109]

25. Fujimoto M, Fujimoto Y, Poe JC, Jansen PJ, Lowell CA, DeFranco AL, Tedder TF. CD19 regulates Src family protein tyrosine kinase activation in B lymphocytes through processive amplification. Immunity 2000;13:47-57. [PubMed: 10933394]

26. DeFranco AL, Chan VW, Lowell CA. Positive and negative roles of the tyrosine kinase Lyn in B cell function. Semin Immunol 1998;10:299-307. [PubMed: 9695186]

27. Niiro H, Clark EA. Regulation of B-cell fate by antigen-receptor signals. Nat Rev Immunol 2002;2:945-956. [PubMed: 12461567]

28. Fujimoto M, Poe JC, Jansen PJ, Sato S, Tedder TF. CD19 amplifies B lymphocyte signal transduction by regulating Src-family protein tyrosine kinase activation. J Immunol 1999;162:7088-7094. [PubMed: 10358152]

29. Li X, Carter RH. Convergence of CD19 and B cell antigen receptor signals at MEK1 in the ERK2 activation cascade. J Immunol 1998;161:5901-5908. [PubMed: 9834070]

30. Culton DA, Nicholas MW, Bunch DO, Zhen QL, Kepler TB, Dooley MA, Mohan C, Nachman PH, Clarke SH. Similar CD19 Dysregulation in Two Autoantibody-Associated Autoimmune Diseases Suggests a Shared Mechanism of B-Cell Tolerance Loss. J Clin Immunol 2007;27:53-68. [PubMed: 17195045]

31. Sato S, Fujimoto M, Hasegawa M, Takehara K. Altered blood B lymphocyte homeostasis in systemic sclerosis: expanded naive B cells and diminished but activated memory B cells. Arthritis Rheum 2004;50:1918-1927. [PubMed: 15188368]

32. Wehr C, Eibel H, Masilamani M, Illges H, Schlesier M, Peter HH, Warnatz K. A new CD21low B cell population in the peripheral blood of patients with SLE. Clin Immunol 2004;113:161-171. [PubMed: 15451473]

33. Warnatz K, Wehr C, Drager R, Schmidt S, Eibel H, Schlesier M, Peter HH. Expansion of CD19(hi) $\mathrm{CD} 21(\mathrm{lo} / \mathrm{neg}) \mathrm{B}$ cells in common variable immunodeficiency (CVID) patients with autoimmune cytopenia. Immunobiology 2002;206:502-513. [PubMed: 12607725]

34. Culton DA, O'Conner BP, Conway KL, Diz R, Rutan J, Vilen BJ, Clarke SH. Early preplasma cells define a tolerance checkpoint for autoreactive B cells. J Immunol 2006;176:790-802. [PubMed: 16393962]

35. Anolik JH, Barnard J, Owen T, Zheng B, Kemshetti S, Looney RJ, Sanz I. Recovery of peripheral blood memory B cells after rituximab treatment in SLE is delayed and lags behind lymphoid tissue memory B cell reconstitution. Arthritis Rheum. 2007 In press.

36. Looney RJ, Anolik JH, Campbell D, Felgar RE, Young F, Arend LJ, Sloand JA, Rosenblatt J, Sanz I. B cell depletion as a novel treatment for systemic lupus erythematosus: a phase I/II dose-escalation trial of rituximab. Arthritis Rheum 2004;50:2580-2589. [PubMed: 15334472]

37. Lankester AC, Rood PM, van Schijndel GM, Hooibrink B, Verhoeven AJ, van Lier RA. Alteration of B-cell antigen receptor signaling by CD19 co-ligation. A study with bispecific antibodies. J Biol Chem 1996;271:22326-22330. [PubMed: 8798392]

38. Rui L, Vinuesa CG, Blasioli J, Goodnow CC. Resistance to CpG DNA-induced autoimmunity through tolerogenic B cell antigen receptor ERK signaling. Nat Immunol 2003;4:594-600. [PubMed: 12740574]

39. Budman DR, Merchant EB, Steinberg AD, Doft B, Gershwin ME, Lizzio E, Reeves JP. Increased spontaneous activity of antibody-forming cells in the peripheral blood of patients with active SLE. Arthritis Rheum 1977;20:829-833. [PubMed: 324483]

40. Blaese RM, Grayson J, Steinberg AD. Increased immunoglobulin-secreting cells in the blood of patients with active systemic lupus erythematosus. Am J Med 1980;69:345-350. [PubMed: 6998292] 
41. Liossis SN, Kovacs B, Dennis G, Kammer GM, Tsokos GC. B cells from patients with systemic lupus erythematosus display abnormal antigen receptor-mediated early signal transduction events. J Clin Invest 1996;98:2549-2557. [PubMed: 8958217]

42. Tsokos GC, Wong HK, Enyedy EJ, Nambiar MP. Immune cell signaling in lupus. Curr Opin Rheumatol 2000;12:355-363. [PubMed: 10990169]

43. Tangye SG, Liu YJ, Aversa G, Phillips JH, de Vries JE. Identification of functional human splenic memory B cells by expression of CD148 and CD27. J Exp Med 1998;188:1691-1703. [PubMed: 9802981]

44. Lin KI, Angelin-Duclos C, Kuo TC, Calame K. Blimp-1-dependent repression of Pax-5 is required for differentiation of B cells to immunoglobulin M-secreting plasma cells. Mol Cell Biol 2002;22:4771-4780. [PubMed: 12052884]

45. Lopez F, Belloc F, Lacombe F, Dumain P, Reiffers J, Bernard P, Boisseau MR. Modalities of synthesis of Ki67 antigen during the stimulation of lymphocytes. Cytometry 1991;12:42-49. [PubMed: 1999122]

46. Scholzen T, Gerdes J. The Ki-67 protein: from the known and the unknown. J Cell Physiol 2000;182:311-322. [PubMed: 10653597]

47. Loke P, MacDonald AS, Robb A, Maizels RM, Allen JE. Alternatively activated macrophages induced by nematode infection inhibit proliferation via cell-to-cell contact. Eur J Immunol 2000;30:2669-2678. [PubMed: 11009101]

48. Gunn MD, Ngo VN, Ansel KM, Ekland EH, Cyster JG, Williams LT. A B-cell-homing chemokine made in lymphoid follicles activates Burkitt's lymphoma receptor-1. Nature 1998;391:799-803. [PubMed: 9486651]

49. Hargreaves DC, Hyman PL, Lu TT, Ngo VN, Bidgol A, Suzuki G, Zou YR, Littman DR, Cyster JG. A coordinated change in chemokine responsiveness guides plasma cell movements. J Exp Med 2001;194:45-56. [PubMed: 11435471]

50. Muehlinghaus G, Cigliano L, Huehn S, Peddinghaus A, Leyendeckers H, Hauser AE, Hiepe F, Radbruch A, Arce S, Manz RA. Regulation of CXCR3 and CXCR4 expression during terminal differentiation of memory B cells into plasma cells. Blood 2005;105:3965-3971. [PubMed: 15687242]

51. Hauser AE, Debes GF, Arce S, Cassese G, Hamann A, Radbruch A, Manz RA. Chemotactic responsiveness toward ligands for CXCR3 and CXCR4 is regulated on plasma blasts during the time course of a memory immune response. J Immunol 2002;169:1277-1282. [PubMed: 12133949]

52. Odendahl M, Mei H, Hoyer BF, Jacobi AM, Hansen A, Muehlinghaus G, Berek C, Hiepe F, Manz R, Radbruch A, Dorner T. Generation of migratory antigen-specific plasma blasts and mobilization of resident plasma cells in a secondary immune response. Blood 2005;105:1614-1621. [PubMed: 15507523]

53. Loetscher M, Loetscher P, Brass N, Meese E, Moser B. Lymphocyte-specific chemokine receptor CXCR3: regulation, chemokine binding and gene localization. Eur J Immunol 1998;28:3696-3705. [PubMed: 9842912]

54. Otero DC, Omori SA, Rickert RC. Cd19-dependent activation of Akt kinase in B-lymphocytes. J Biol Chem 2001;276:1474-1478. [PubMed: 11042164]

55. Pogue SL, Kurosaki T, Bolen J, Herbst R. B cell antigen receptor-induced activation of Akt promotes B cell survival and is dependent on Syk kinase. J Immunol 2000;165:1300-1306. [PubMed: 10903730]

56. Martin P, Duran A, Minguet S, Gaspar ML, Diaz-Meco MT, Rennert P, Leitges M, Moscat J. Role of zeta PKC in B-cell signaling and function. Embo J 2002;21:4049-4057. [PubMed: 12145205]

57. Reimold AM, Ponath PD, Li YS, Hardy RR, David CS, Strominger JL, Glimcher LH. Transcription factor B cell lineage-specific activator protein regulates the gene for human X-box binding protein 1. J Exp Med 1996;183:393-401. [PubMed: 8627152]

58. Shaffer AL, Yu X, He Y, Boldrick J, Chan EP, Staudt LM. BCL-6 represses genes that function in lymphocyte differentiation, inflammation, and cell cycle control. Immunity 2000;13:199-212. [PubMed: 10981963]

59. Lin KI, Tunyaplin C, Calame K. Transcriptional regulatory cascades controlling plasma cell differentiation. Immunol Rev 2003;194:19-28. [PubMed: 12846804] 
60. Shaffer AL, Lin KI, Kuo TC, Yu X, Hurt EM, Rosenwald A, Giltnane JM, Yang L, Zhao H, Calame K, Staudt LM. Blimp-1 orchestrates plasma cell differentiation by extinguishing the mature B cell gene expression program. Immunity 2002;17:51-62. [PubMed: 12150891]

61. Cyster JG. Homing of antibody secreting cells. Immunol Rev 2003;194:48-60. [PubMed: 12846807]

62. Cassese G, Arce S, Hauser AE, Lehnert K, Moewes B, Mostarac M, Muehlinghaus G, Szyska M, Radbruch A, Manz RA. Plasma cell survival is mediated by synergistic effects of cytokines and adhesion-dependent signals. J Immunol 2003;171:1684-1690. [PubMed: 12902466]

63. Cassese G, Lindenau S, de Boer B, Arce S, Hauser A, Riemekasten G, Berek C, Hiepe F, Krenn V, Radbruch A, Manz RA. Inflamed kidneys of NZB / W mice are a major site for the homeostasis of plasma cells. Eur J Immunol 2001;31:2726-2732. [PubMed: 11536171]

64. Tsubaki T, Takegawa S, Hanamoto H, Arita N, Kamogawa J, Yamamoto H, Takubo N, Nakata S, Yamada K, Yamamoto S, Yoshie O, Nose M. Accumulation of plasma cells expressing CXCR3 in the synovial sublining regions of early rheumatoid arthritis in association with production of Mig/ CXCL9 by synovial fibroblasts. Clin Exp Immunol 2005;141:363-371. [PubMed: 15996201]

65. Meller S, Winterberg F, Gilliet M, Muller A, Lauceviciute I, Rieker J, Neumann NJ, Kubitza R, Gombert M, Bunemann E, Wiesner U, Franken-Kunkel P, Kanzler H, Dieu-Nosjean MC, Amara A, Ruzicka T, Lehmann P, Zlotnik A, Homey B. Ultraviolet radiation-induced injury, chemokines, and leukocyte recruitment: An amplification cycle triggering cutaneous lupus erythematosus. Arthritis Rheum 2005;52:1504-1516. [PubMed: 15880822]

66. Lit LC, Wong CK, Tam LS, Li EK, Lam CW. Raised plasma concentration and ex vivo production of inflammatory chemokines in patients with systemic lupus erythematosus. Ann Rheum Dis 2006;65:209-215. [PubMed: 15975968]

67. Narumi S, Takeuchi T, Kobayashi Y, Konishi K. Serum levels of ifn-inducible PROTEIN-10 relating to the activity of systemic lupus erythematosus. Cytokine 2000;12:1561-1565. [PubMed: 11023674]

68. Avihingsanon Y, Phumesin P, Benjachat T, Akkasilpa S, Kittikowit V, Praditpornsilpa K, Wongpiyabavorn J, Eiam-Ong S, Hemachudha T, Tungsanga K, Hirankarn N. Measurement of urinary chemokine and growth factor messenger RNAs: a noninvasive monitoring in lupus nephritis. Kidney Int 2006;69:747-753. [PubMed: 16518330]

69. Okamoto H, Katsumata Y, Nishimura K, Kamatani N. Interferon-inducible protein 10/CXCL10 is increased in the cerebrospinal fluid of patients with central nervous system lupus. Arthritis Rheum 2004;50:3731-3732. [PubMed: 15529358]

70. Okamoto H, Iikuni N, Kamitsuji S, Yoshio T, Minota S, Kamatani N. IP-10/MCP-1 ratio in CSF is an useful diagnostic marker of neuropsychiatric lupus patients. Rheumatology (Oxford) 2006;45:232-234. [PubMed: 16377728]

71. Hirohata S, Miyamoto T. Increased intrathecal immunoglobulin synthesis of both kappa and lambda types in patients with systemic lupus erythematosus and central nervous system involvement. $\mathrm{J}$ Rheumatol 1986;13:715-721. [PubMed: 3095548]

72. Sfikakis PP, Boletis JN, Tsokos GC. Rituximab anti-B-cell therapy in systemic lupus erythematosus: pointing to the future. Curr Opin Rheumatol 2005;17:550-557. [PubMed: 16093832]

73. Martin F, Chan AC. B cell immunobiology in disease: evolving concepts from the clinic. Annu Rev Immunol 2006;24:467-496. [PubMed: 16551256] 


\section{A \\ Clinical Response to Rituximab}

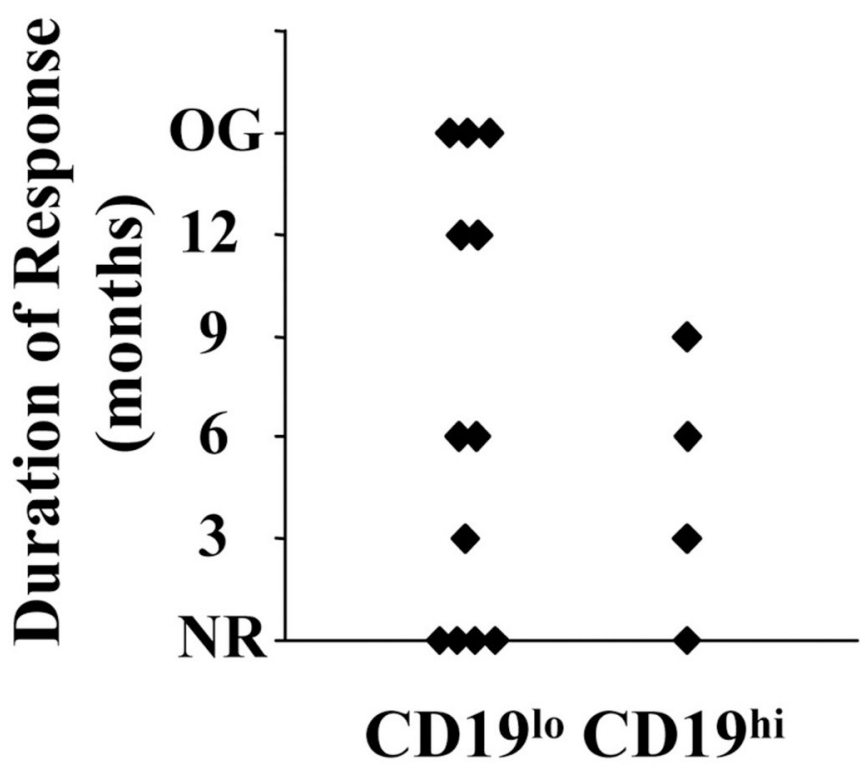

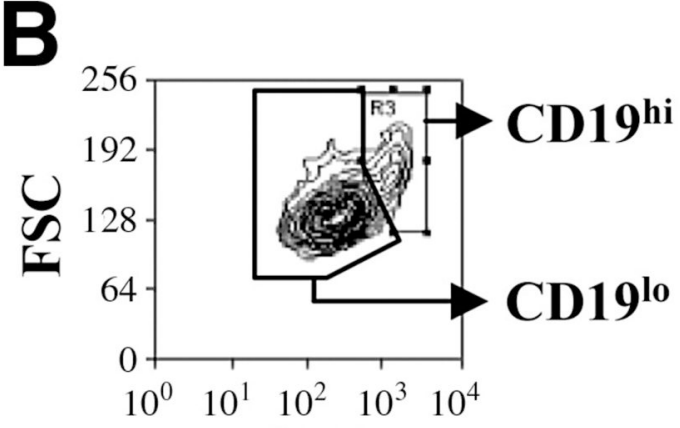

CD19

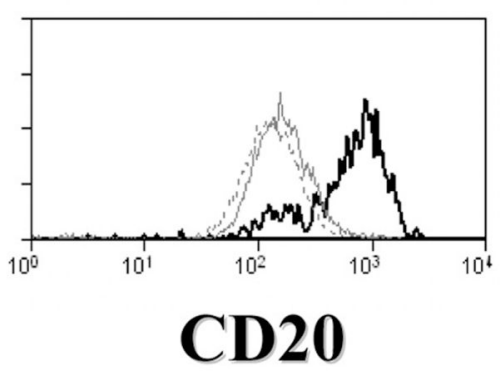

- - - - HC B cells CD19 ${ }^{\text {lo }}$ SLE B cells CD19 ${ }^{\text {hi }}$ SLE B cells

Fig. 1. CD19 ${ }^{\text {hi }}$ patients are poor responders to rituximab treatment

A, Clinical response of CD19hi SLE patients and CD19 ${ }^{\text {lo }}$ SLE patients to rituximab treatment. Response was defined as an improvement in the SLAM or SLEDAI score of at least 3 points and duration of response defined as the time point at which these disease activity indexes increased by 3 points or an increase in steroid dosage was required. $\mathrm{NR}=$ no response; $\mathrm{OG}=$ ongoing response. $\mathbf{B}$, Representative histograms showing gating for $\mathrm{CD} 19^{\mathrm{hi}}$ and $\mathrm{CD} 19^{\mathrm{lo}} \mathrm{B}$ cells from an SLE patient. Only CD $19^{+} \mathrm{PB}$ B cells are included in this gate. The bottom histogram shows CD20 expression by CD19hi and CD19lo $\mathrm{B}$ cells and healthy control $\mathrm{B}$ cells (all CD19+ $\mathrm{B}$ cells). Results are representative of 3 patients. 

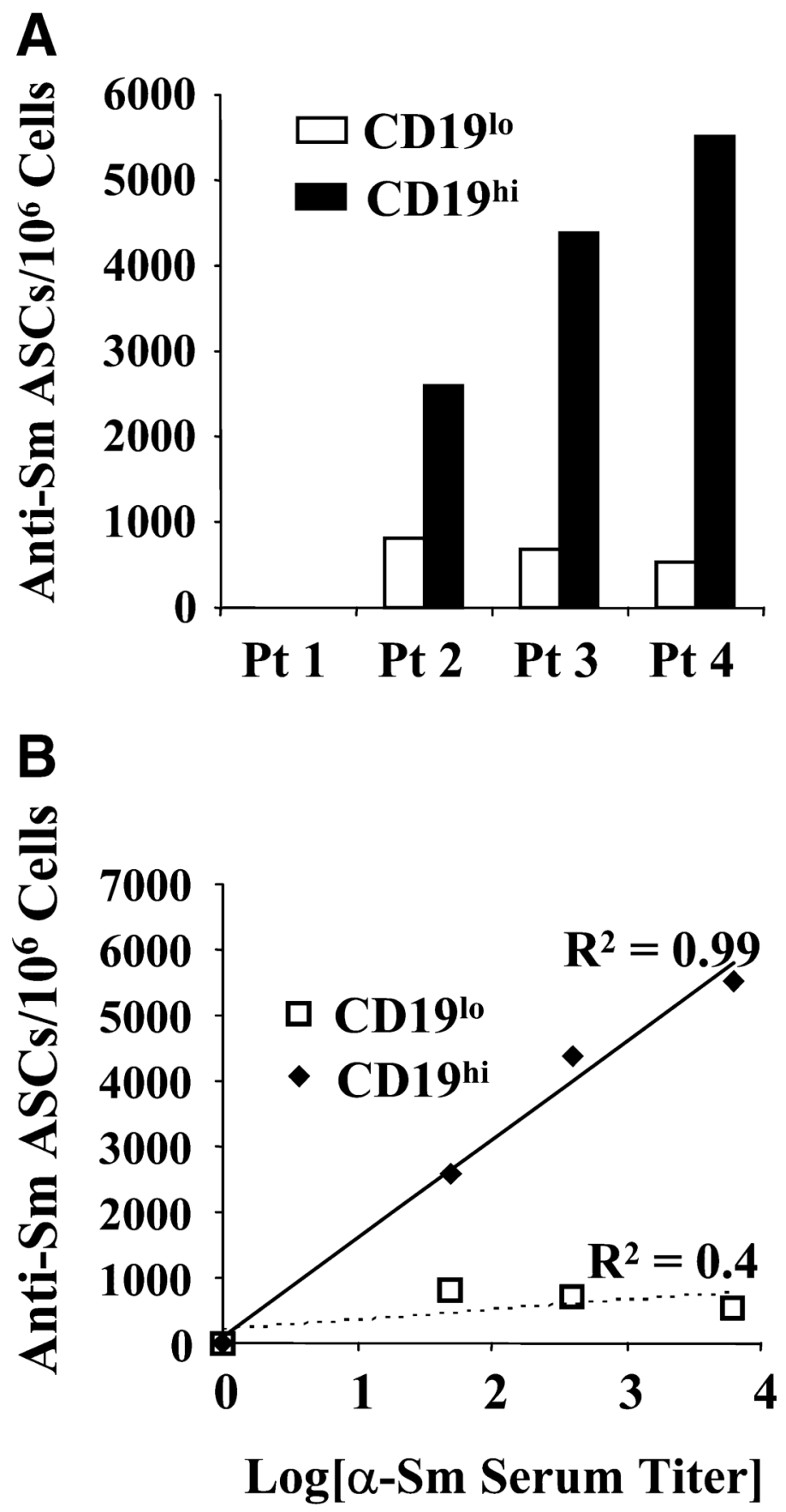

Fig. 2. CD19 ${ }^{\text {hi }}$ B cells are enriched for autoreactivity, and the degree of autoreactivity in these cells correlates exponentially with serum autoantibody titers

A, CD $19^{\text {hi }}$ and CD $19^{\text {lo }}$ B cells were sorted (using gates illustrated in Fig. 1B) from four patients with differing anti-Sm titers, and ELISpot used to determine the number of anti-Sm IgG ASCs in each group with and without stimulation by pansorbin, anti-CD40, IL-10 and IL-2. B, AntiSm ASCs per million CD19hi or CD19 ${ }^{\text {lo }} \mathrm{B}$ cells in each of four patients. Patient 1 did not have detectable serum anti-Sm titer, and no anti-Sm ASCs were seen in either cell group. C, AntiSm ASCs per million cells in each group vs. $\log _{10}$ [anti-Sm serum titer], showing an exponential relationship between the number of anti-Sm ASCs in the CD19hi B cell group and the serum titer of anti-Sm in the corresponding patient. 

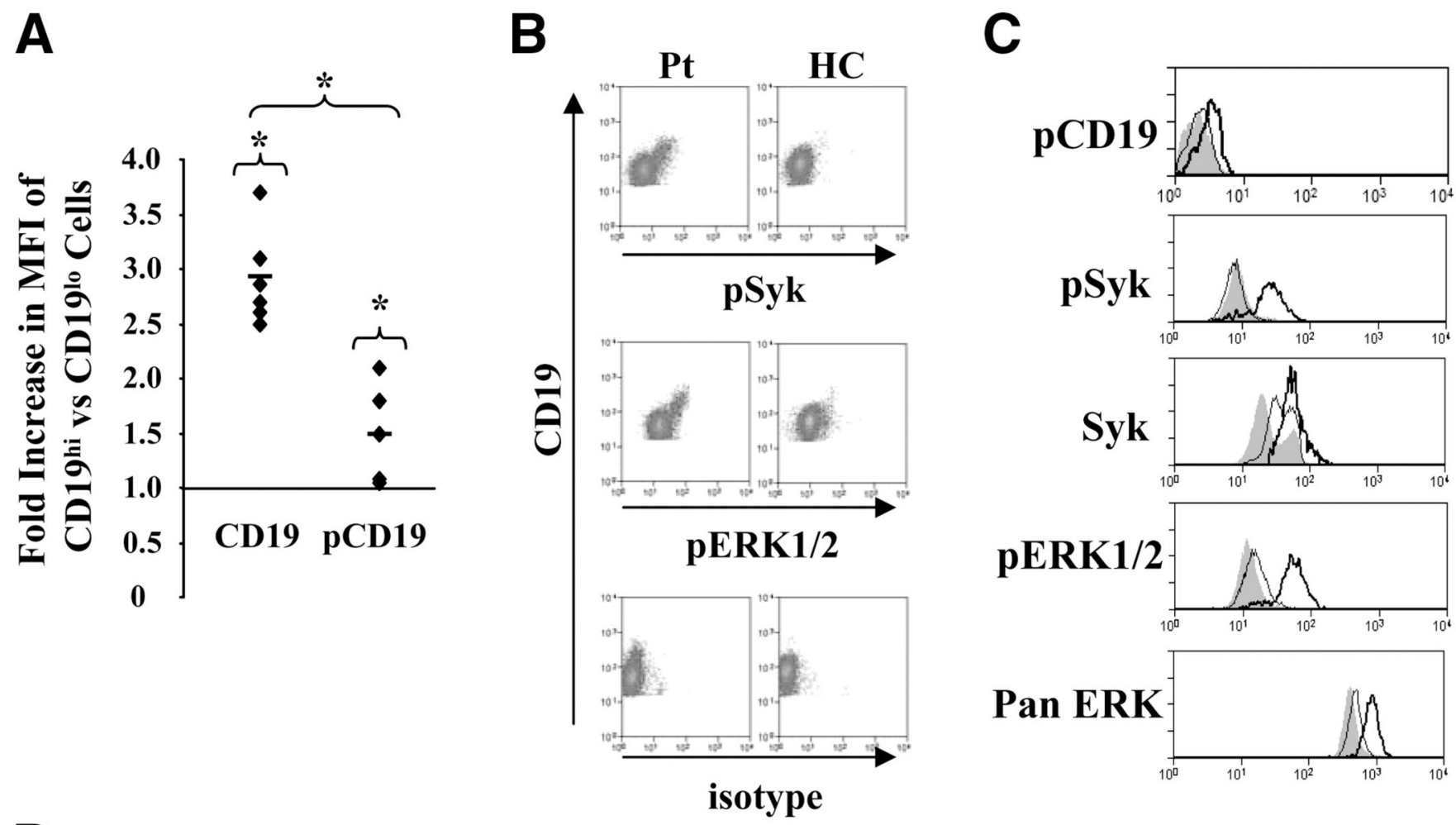

D

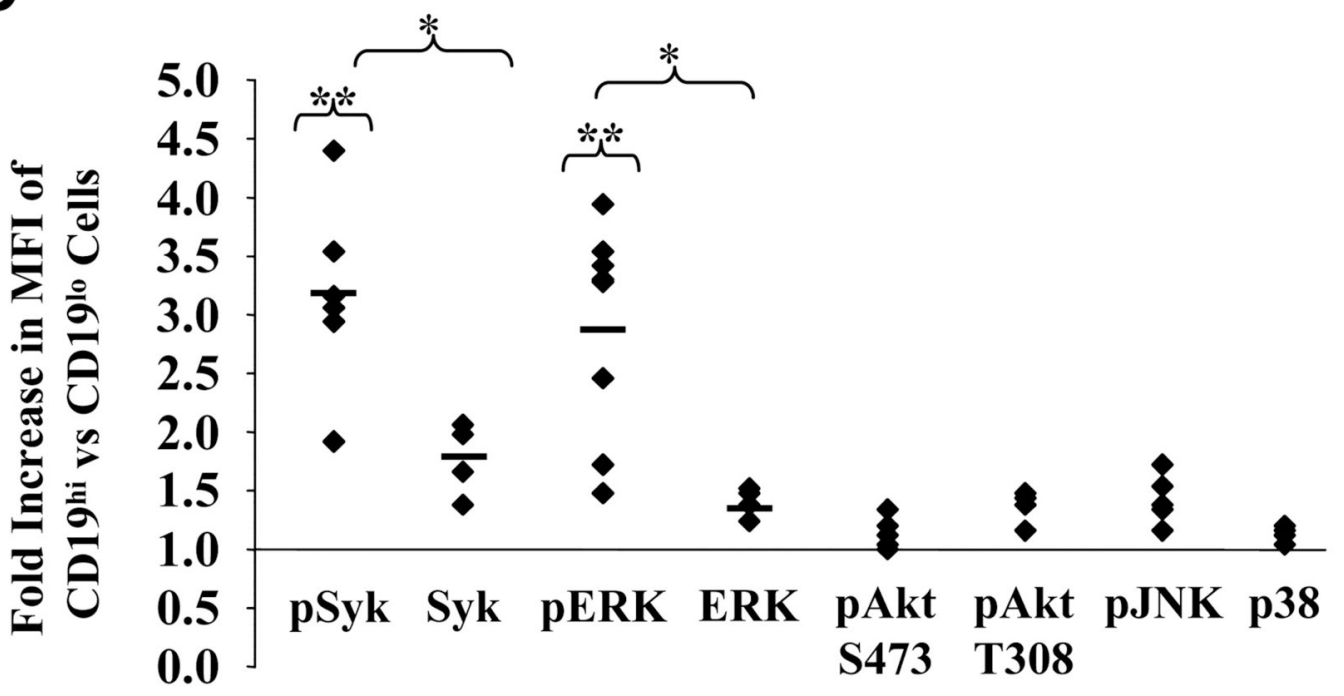

Fig. 3. Basal phosphorylative state of $\mathrm{CD19}$ hi cells

PB cells were permeabilized and stained using antibodies recognizing the indicated molecules. Gating for CD19hi and CD19 ${ }^{\text {lo }}$ B cells is shown in Fig. 1B. A, Fold increase in MFIs of CD19 or phosphorylated CD19 (pCD19) in CD19 hi vs CD19 ${ }^{\text {lo }}$ cells. B, Representative histograms of PB cells from a CD19hi patient and healthy control (HC) stained for CD19 and pSyk, pERK1/2, or an isotype control. Gating is on all CD19 ${ }^{+}$B cells. C, Representative single parameter histograms showing staining for phosphorylated CD19 and phosphorylated or total Syk and ERK1/2 in PB B cells from a healthy control (shaded) and CD19 ${ }^{\text {lo }}$ (thin line) and CD19hi (thick line) B cells from the same patient. Gating is on CD19hi and CD19lo B cells as shown in Fig. 1B. D, Fold increases in MFI for the labeled signaling molecules in CD19 ${ }^{\text {lo }}$ vs. 
CD19hi cells from the same patient. A and D, Each dot represents a different patient and/or day. At least four different patients are included for each signaling molecule. ${ }^{*} \mathrm{p} \leq 0.05$; $* * \mathrm{p} \leq 0.001$. 


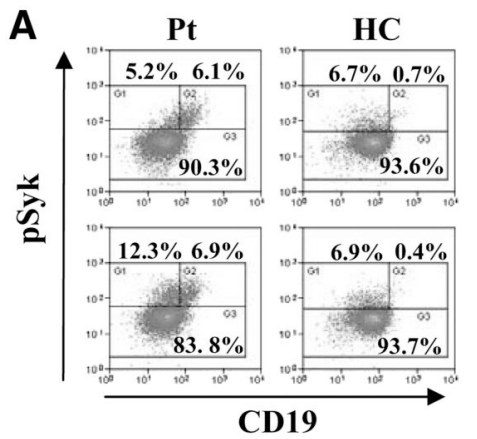

B
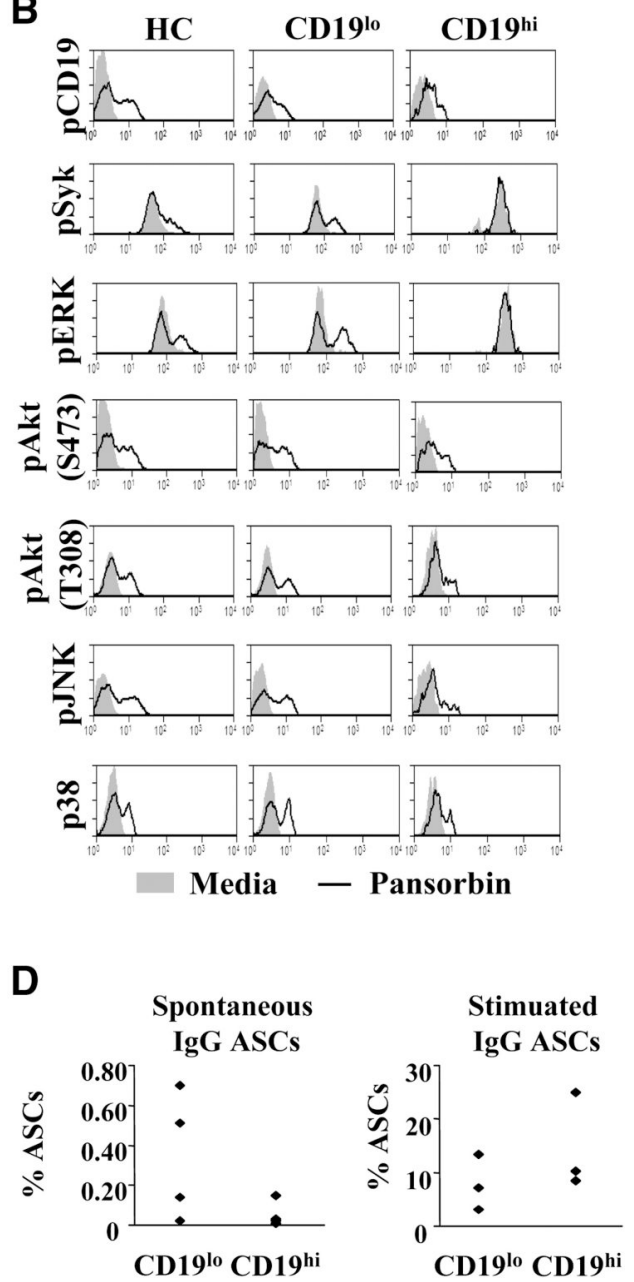
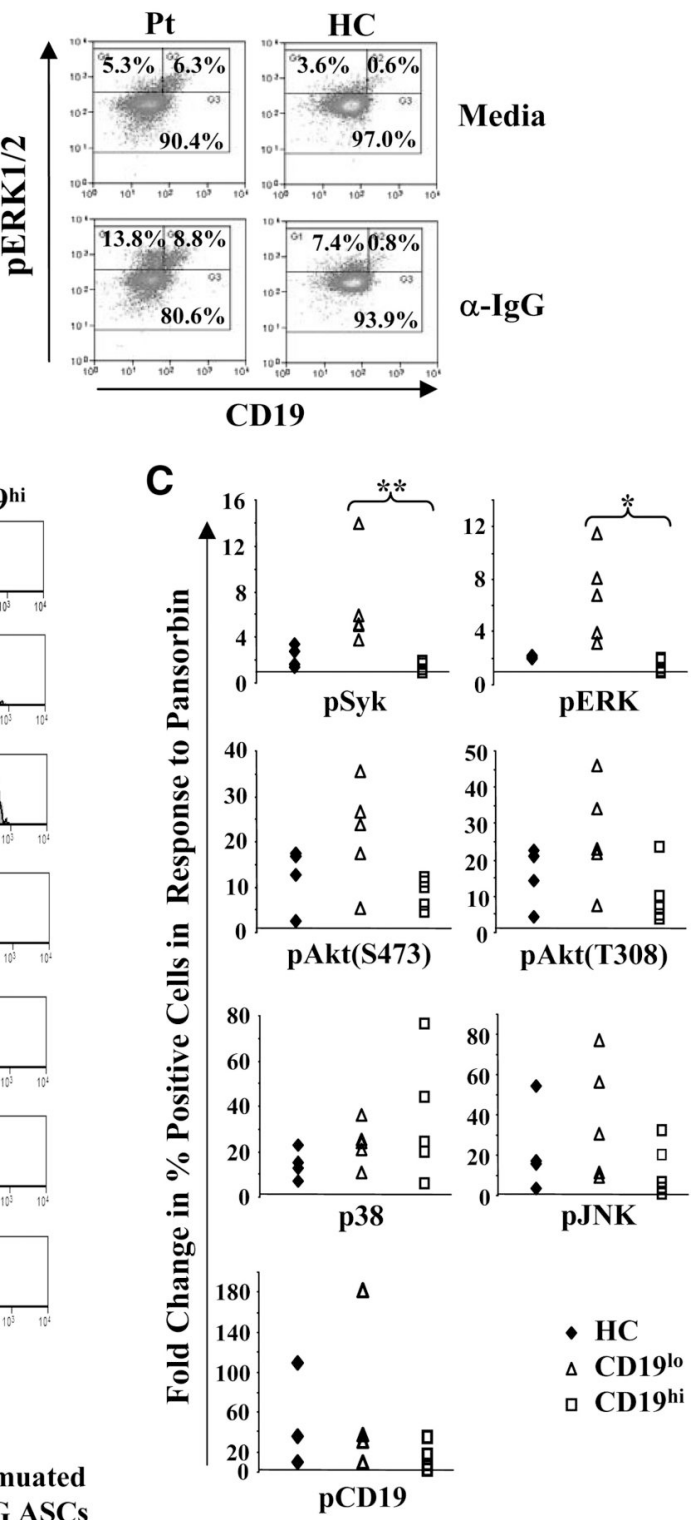

Fig. 4. CD19 ${ }^{\text {hi }} B$ cells respond to BCR crosslinking

A, Representative histograms of PB B cells from a CD19hi patient and a healthy control after incubation with media alone or with anti-IgG for 10 min. Histograms are gated on CD19+ PB $\mathrm{B}$ cells and the percentages give are of B cells falling within each indicated gate. $\mathbf{B}$,

Representative single parameter histograms for each of the indicated phosphorylated molecules in PB B cells from a healthy control and CD19lo and CD19hi B cells from a patient after incubation with media (shaded) or pansorbin (line) for 10 min. Gating is illustrated in Fig. 1B. C, Fold change in the percentage of cells falling into the positive gate for each of the phosphorylated signaling molecules tested in cells incubated with media or pansorbin in a healthy control or in $\mathrm{CD} 19^{\mathrm{lo}}$ and $\mathrm{CD} 19^{\mathrm{hi}} \mathrm{B}$ cells from the same patient. Each point represents 
a different individual. D, CD19 hi and CD19 ${ }^{\text {lo }}$ B cells (see Fig. 2A) were sorted and IgG antibody secreting cells (ASCs) determined after incubation with either media alone or with pansorbin, anti-CD40, IL-10 and IL-2 for 6 days. Each dot represents a different patient. * $\mathrm{p} \leq 0.05$;

$* * \mathrm{p} \leq 0.001$. 

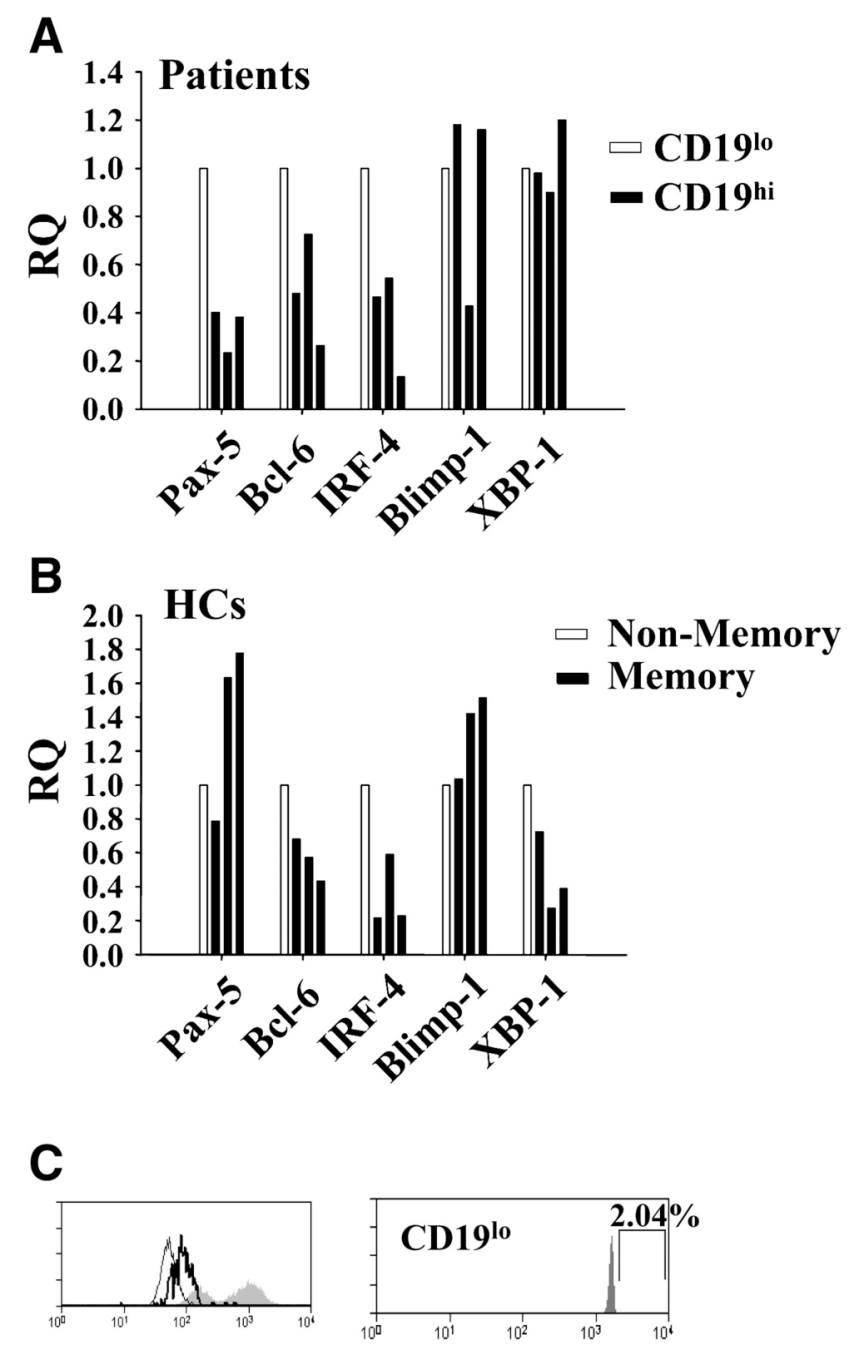

Ki-67
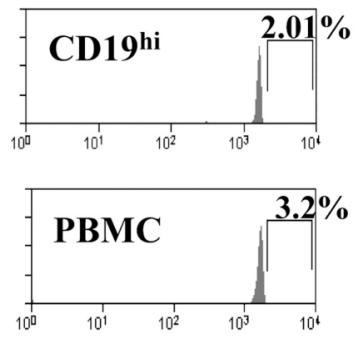

PI

Fig. 5. CD19 ${ }^{\text {hi }} \mathrm{B}$ cells have altered transcription factor expression

$\mathbf{A}$ and $\mathbf{B}$, Transcription factor expression in indicated sorted B cell groups as determined by RQ RT-PCR. Each bar represents a different individual. Gating for cell sorting is shown in Fig. 1B. A, Relative expression in CD19hi $\mathrm{B}$ cells as compared to $\mathrm{CD} 19^{\text {lo }} \mathrm{B}$ cells from the same patient. B, Relative expression in $\mathrm{CD} 19^{+} \mathrm{CD} 38^{-} \mathrm{IgD}{ }^{-}$memory $\mathrm{B}$ cells as compared to all other CD19+ B cells from the same healthy control. C, Representative histograms for Ki-67 staining in non-lymphoid PBMCs (shaded) and CD19 ${ }^{\text {lo }}$ (thin line) or CD19hi (thick line) patient PB B cells and for PI staining of indicated subsets. Percentages indicate cells falling into drawn gate. 
A

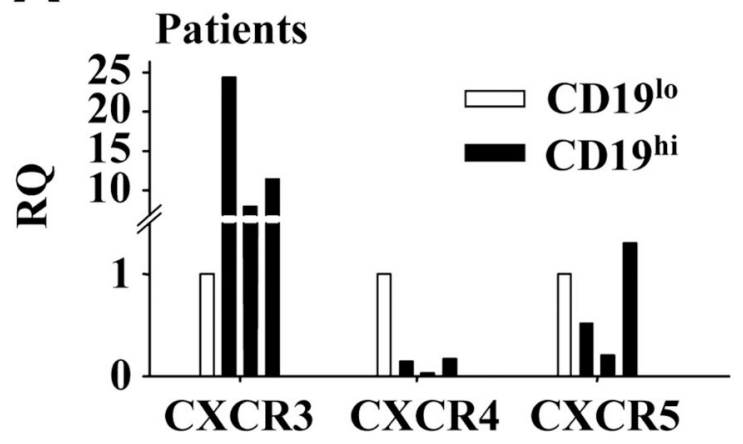

B
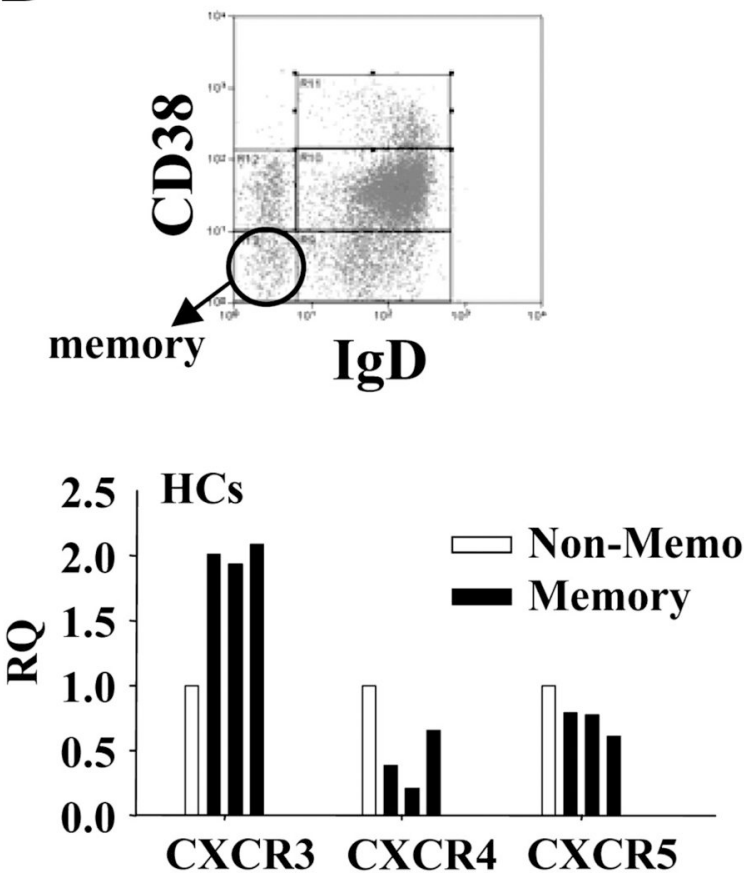

C

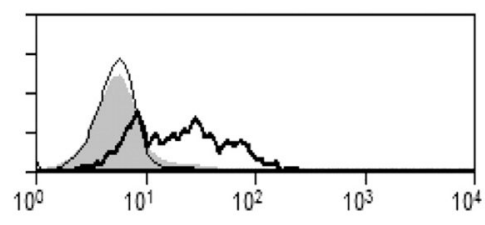

CXCR3

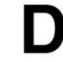

Fig 6. CXCR expression in patient CD19 ${ }^{\text {hi }}$ and healthy control memory $B$ cells

A and B, CXCR expression in indicated sorted B cell groups as determined by RQ RT-PCR. Each bar represents a different individual. A, Relative expression in CD19hi B cells as compared to CD19 ${ }^{\text {lo }} \mathrm{B}$ cells from the same patient. B, Representative histogram of CD19 ${ }^{+} \mathrm{B}$ cells from a healthy control showing gating of memory B cells (circled; CD38-, IgD-). The non-memory B cells used were gated as all CD $19^{+} \mathrm{B}$ cells that fell outside this gate. Bars represent relative transcript expression in $\mathrm{CD}_{19}{ }^{+} \mathrm{CD} 38^{-} \mathrm{IgD}^{-}$memory B cells as compared to all other CD19 ${ }^{+}$B cells from the same healthy control. C, Surface CXCR3 expression determined by flow cytometry on healthy control B cells (shaded) or in CD19 ${ }^{\text {lo }}$ (thin line) or CD19hi (thick line) B cells from the same patient. Histogram is representative of three patients. D, Chemotaxis of CD19hi B cells in response to the CXCR3 ligand CXCL9, the CXCR4 ligand CXCL12, or media alone. Migration was determined by collection, staining, and flow cytometry of cells which migrated into lower wells after 90 minutes. No chemotaxis was observed in response to CXCL12 and media alone by cells from patient 2. 
Table 1

Long-term Clinical Outcomes

\begin{tabular}{|c|c|c|c|}
\hline Complication/Outcome & CD19 $^{\text {lo }}$ Patients & CD19 $^{\text {hi }}$ Patients & $\boldsymbol{p}$ value \\
\hline Severe Neurological & $0 \%(0 / 27)$ & $29 \%(4 / 14)$ & 0.01 \\
\hline ESRD & $4 \%(1 / 27)$ & $29 \%(4 / 14)$ & 0.04 \\
\hline TTP & $7 \%(2 / 27)$ & $7 \%(1 / 14)$ & 1.0 \\
\hline Death & $4 \%(1 / 27)$ & $14 \%(2 / 14)$ & 0.26 \\
\hline Any Adverse & $15 \%(4 / 27)$ & $64 \%(9 / 14)$ & 0.003 \\
\hline
\end{tabular}


Table 2

Cell Cycle analysis of CD19hi B Cells

\begin{tabular}{|c|c|c|c|}
\hline & Fold Ki-67 & CD19 $^{\text {hi }}$ \% PI High & CD19 $^{\text {Io } \% \text { PI High }}$ \\
\hline Patient 1 & 1.78 & $2.30 \%$ & $2.80 \%$ \\
\hline Patient 2 & 1.72 & $3.03 \%$ & $3.51 \%$ \\
\hline Patient 3 & 1.54 & $2.04 \%$ & $2.04 \%$ \\
\hline
\end{tabular}

${ }^{1}$ Fold increase in MFI for Ki-67 in CD19 ${ }^{\text {hi }}$ vs CD19 ${ }^{\text {lo }}$ B cells.

${ }^{2}$ Percentage of $\mathrm{CD} 19^{\text {hi }}$ or $\mathrm{CD} 19^{\mathrm{lo}} \mathrm{B}$ cells falling into a gate indicating high propidium iodide content (S phase). 